\title{
The first Portuguese Textbooks of the German Language, based on the Method Gaspey-Otto-Sauer
}

\author{
Rolf KEMMLER (1) \\ Universidade de Trás-os-Montes e Alto Douro (UTAD)
}

\section{○}

OPEN ACCESS

\section{EDITED BY}

- Gonçalo Fernandes (UTAD)

- Leonardo Ferreira Kaltner (UFF)

- Ronaldo Batista (UPM)

REVIEWED BY

- Ricardo Cavaliere (UFF)

- Nancy Casagrande (PUC-SP)

DATES

- Received: 09/06/2021

- Accepted: 09/16/2021

- Published: 12/09/2021

HOW TO CITE

Kemmler, R. (2021). The first Portuguese Textbooks of the German Language, based on the Method Gaspey-Otto-Sauer. Revista da Abralin, v. 20, n. 3 , p. 411-429, 2021.

\section{ABSTRACT}

In addition to other works designed to support the acquisition of modern foreign languages from the second half of the nineteenth century onwards, the so-called 'conversation grammars' and 'elementary grammars' of the Heidelberg Julius Groos Verlag occupy a central position in the teaching concept of this publishing house, which is still referred to today as the Method Gaspey-Otto-Sauer (MGOS). This paper explores the relationship between a contemporary edition of the French language conversation grammar Nouvelle grammaire allemande (1882) and the first edition of the Portuguese language Nova grammatica allemã theorica e pratica (1887), as well as the elementary grammars Petite grammaire allemande (1881) and Grammatica elementar allemã: adaptada á lingua portugueza (1887). In particular, this paper examines how the editor or author José Prévôt (fl. 1887) proceeded in preparing the editions for which he ultimately assumed responsibility.

\section{RESUMO}

A par de outras obras destinadas a apoiar a aquisição de línguas estrangeiras modernas a partir da segunda metade do século XIX, as chamadas 'gramáticas de conversação' e as 'gramáticas elementares', publicados pela editora Julius Groos Verlag em Heidelberg ocupam uma posição central no conceito didático ainda hoje referido como o 'Metódo Gaspey-Otto-Sauer' (MGOS). Este artigo examina a relação entre uma edição contemporânea da Nouvelle grammaire allemande (1882) e a primeira edição da Nova Grammatica Allemã Theorica e Pratica (1887), bem como 


\section{REVISTA DA ABRALIN}

a Petite grammaire allemande (1881) e a Grammatica Elementar Allemã: adaptada á lingua portugueza (1887). Em particular, examina-se como o editor / autor José Prévôt (fl. 1887) procedeu na compilação das edições pelas quais foi responsável.

\section{KEYWORDS}

Historiography of linguistics. Method Gaspey-Otto-Sauer. Emil Otto. German grammar.

\section{PALAVRAS-CHAVE}

Historiografia Linguística. Método Gaspey-Otto-Sauer. Emil Otto. Gramática Alemã.

\section{Introduction $^{1}$}

The Heidelberg publishing house Julius Groos Verlag began publishing foreign language textbooks for the Portuguese market in 1887 with the conversation grammar ${ }^{2}$ Nova grammatica allemã theorica e pratica (OTTO; PRÉVÔT, 1887) and the elementary grammar Grammatica elementar allemã: adaptada á lingua portugueza (PRÉVÔT, 1887), published in the same series. The publication of the two works, for which José Prévôt (fl. 1887) was responsible as translator, was due to the Heidelberg printer Friedrich Wolff (1830-1906), who had been co-owner and publishing director of the increasingly internationally active publishing house since 1884 (KEMMLER, 2021a, p. 84-85).

In addition to other works of the Heidelberg publishing house, which were conceived to support the acquisition of various languages, the conversation grammars and elementary grammars in particular occupy a central position in the teaching concept which is still known today as the Method GaspeyOtto-Sauer (MGOS).

While I have proven (KEMMLER, 2021b, p. 127, 158) that the Nova grammatica allemã theorica $e$ pratica can be seen as a translation or adaptation of Emil Otto's (1813-1878)1857 French language Nouvelle grammaire allemande (see OTTO, 1865; OTTO, 1882), it is particularly worth examining whether the

\footnotetext{
${ }^{1}$ Research project funded by the Portuguese Foundation for Science and Technology (FCT), through the Center for Studies in Letters (CEL), reference no. UIDP/00707/2020, Portugal.

2 Regarding the terminology of the volumes belonging to the MGOS teaching concept, it must be explained that in German the terms Conversations Grammatik (OTTO, 1854) Sprachführer were used, while in French the terms Nouvelle grammaire allemande (OTTO, 1865) 'Petite grammaire allemande' (OTTO, 1871) and in English the terms Conversation grammar (OTTO, 1870) Elementary grammar (OTTO, 1890) were applied.
} 


\section{REVISTA DA ABRALIN}

French language elementary grammar Petite grammaire allemande (OTTO, 1871), first published in 1870, stood godmother to the Grammatica elementar allemã to the same extent.

\section{German textbooks of the MGOS series}

While the Portuguese first editions were already summarized under the series name Methodo Gaspey-Otto-Sauer, the corresponding French works were initially still published under the author's name. In the following, the most important facts about the French and Portuguese conversation grammars and elementary grammars examined in this article will be briefly presented. ${ }^{3}$

\subsection{The German conversation grammar in French (1857-1942)}

Titled Nouvelle grammaire allemande: contenant outre principales règles de la langue allemande, des thèmes, des lectures et des conversations d'après une méthode à la fois théorique et pratique, the first edition of the conversation grammar, for which Emil Otto himself was responsible, appeared in 1857 (cf. WorldCat OCLC 1040101922, 947712976). ${ }^{4}$

A total of at least twenty-three editions of Otto's German textbook can be documented, the first eleven of which were published by the author himself. ${ }^{5}$ After Emil Otto's death in 1878, the publisher commissioned various editors to revise the work. Thus, the posthumous twelfth edition I use was organized by Dr. Alexandre Mauron (1829-1891), then a Konstanz secondary school professor who

\footnotetext{
3 This does not take into account the solution keys published in parallel in smaller editions, which were published as auxiliary materials to the translation tasks of the conversation grammar (or also in later editions to the elementary grammar). An example of this is the 94-page volume Corrigé des versions et thèmes contenus dans la grammaire allemande (OTTO, 1902), which was published in 1902 in its sixth edition alongside the newly revised 17th edition of the conversation grammar.

4 To date, I have not had access to a copy of this edition. Since the editions of this work are incompletely noted in CHOPPIN; RODRÍGUEZ; PINHEDE (1993), the WorldCat OCLC number is given for purposes of bibliographic reference. This control number allows viewing of relevant holdings records of networked libraries. RK denotes the existence of editions in my possession.

5 The following editions are attributable to Emil Otto himself: $2^{\text {nd }}$ edition, 1865 (RK); $3^{\text {rd }}$ edition, 1867 (OCLC 1013906229); $4^{\text {th }}$ edition (édition double), 1870 (OCLC 37771435, 459036004); $6^{\text {th }}$ edition, 1872 (OCLC 919866527, 971688854); th $^{\text {th }}$ edition, 1873 (OCLC 593109610); $9^{\text {th }}$ édition stéréotypée, 1874 (OCLC 497049529, 79022908, 630592774); $10^{\text {th }}$ édition stéréotypée, 1876 (OCLC 717914704); $11^{\text {th }}$ édition stéréotypée, 1878 (OCLC 61225788, 799327445, 799627005, 928077713). From the sixth edition on, the editions organized by Emil Otto himself occupy XX, 422 pages (the last four pages of the Roman numbered preliminaries are never paginated and are accordingly considered as $[\mathrm{XVI}-\mathrm{XX}]$ in the following).
} 


\section{REVISTA DA ABRALIN}

stemmed from the community of Belfaux in the Swiss canton of Fribourg (Bourqui 1892), only being identified as A. Mauron. ${ }^{6}$

Revision of the seventeenth and eighteenth editions was undertaken by the French secondary school teacher Marius Nicolas (fl. 1902-1910), who at the time is known to have been a teacher at the Lycée Carnot in Paris. ${ }^{7}$

Gottfried Süpfle (1869-after 1945), a secondary school teacher working in Baden, was responsible for editing the nineteenth and twentieth editions as Godefroi Süpfle. ${ }^{8}$ Süpfle's editing was, in turn, supported by the French teacher Louis E. Gauthier (fl. 1929-1943), ${ }^{9}$ but I could not ascertain whether there were further editions of this work after the 23rd edition that was published in 1942.

\subsection{The German elementary grammar in French (1870-1865)}

Under the also quite detailed title Petite grammaire allemande: abrégée, accompagnée de nombreux exercices de conversation et de lecture, a l'usage des commençants, d'après une méthode a la fois théorique et pratique, Emil Otto published the first edition of the elementary grammar (cf. OTTO, 1871, p. VI; OCLC 800562467, 174198486) with VIII, 168 pages, dated May 1870, which demonstrably had at least 18 editions until 1956. ${ }^{10}$

Revised by Alexandre Mauron, two more editions with the same number of pages were published in 1888 and $1896 .{ }^{11}$ After Mauron's death, the three subsequent editions were edited by Paul Isidore Verrier (1860-1938), a university professor in Paris, who added a small vocabulary to the volume for the first time in $1900 .^{12}$ Probably the last revision of the elementary grammar was made by the

\footnotetext{
6 These are the following five editions, all of which were XX 422 pages: $12^{\text {th }}$ edition, 1882 (OCLC 235859652; RK); $13^{\text {th }}$ edition, 1888 (OCLC 804521609, 937693196, 1040120235); $14^{\text {th }}$ edition, 1891 (OCLC 496971410, 839019794, 963459121, 1046357586); $15^{\text {th }}$ edition, 1897 (OCLC 37771443, 401295726, 669364452, 717343696, RK); $16^{\text {th }}$ edition, 1900 (OCLC 55206464, 893918105).

7 The following editions can be identified: $17^{\text {th }}$ edition, 1902 (OCLC 633188230, 633187681, 803323428, 818887952, RK); $18^{\text {th }}$ edition, 1910 (OCLC 43592716, 257479531, 562193518, 608492468, 759705868, 1068205498).

$819^{\text {th }}$ edition, 1920 (OCLC 72325737, 721290773, 829709105); $20^{\text {th }}$ edition, 1923 (OCLC 7015955, 83472120, 491517655, 602230586).

$921^{\text {st }}$ edition, 1929 (OCLC 718564125); 22 ${ }^{\text {nd }}$ edition, 1937 (OCLC 603426194, RK); $23^{\text {rd }}$ edition, 1942 (OCLC 72325733).

10 So far, I have not had access to any copy of the first edition of the elementary grammar. Occupying XII, 172 pages each, four more editions appeared under Otto's name: $2^{\text {nd }}$ edition, 1871 (OCLC 690453446, 1040240695, RK); $3^{\text {rd }}$ edition, 1875 (OCLC 835291131); $4^{\text {th }}$ edition, 1877 (OCLC 901803148); $5^{\text {th }}$ edition, 1881 (OCLC 803815109, RK).

$116^{\text {th }}$ edition, 1888 (OCLC 35291697, 1040088950); $7^{\text {th }}$ edition, 1896 (OCLC 77283789).

$128^{\text {th }}$ edition, 1900 (OCLC 1080072290); $9^{\text {th }}$ edition, 1903 (OCLC 901710801, 912365551); 10 ${ }^{\text {th }}$ edition (OCLC 715310286, 806993480).
} 


\section{REVISTA DA ABRALIN}

aforementioned Gottfried Süpfle, who remained being mentioned as the editor responsible for the last eight editions, even those that were published following his death in $1916 .{ }^{13}$

\subsection{The German conversation grammar in Portuguese (1887-1942)}

The first edition of the Nova grammatica allemã theorica e pratica: contendo alem das principaes regras da lingua allemã, themas e exercicios de leitura e de conversação appeared in 1887 as the work of Emil Otto, but with the explicit indication that the textbook had been «Adaptada ao uso dos portuguezes por José Prévôt» [Adapted for use by the Portuguese by José Prévôt] (OTTO; PRÉVÔT, 1887, p. [I]). As I was able to prove in the course of a complete bibliographical evaluation (cf. KEMMLER, 2021a, p. 122127), a total of seven editions were published $\left({ }^{1} 1887,{ }^{2} 1901,{ }^{3} 1907,{ }^{4} 1913,{ }^{5} 1927,{ }^{5} 1928,{ }^{6} 1933,{ }^{7} 1942\right)$, the fifth edition being published in two variants with indication of the years 1927 and 1928. Since the text of the Portuguese conversation grammar of the German language, for which José Prévôt was responsible, underwent changes by subsequent Portuguese editors from the third edition on, only the first edition is relevant for the purposes of this study.

\subsection{The German elementary grammar in Portuguese (1887-1974)}

With identical orientation in terms of target audience, the first edition of the Grammatica elementar allemã: adaptada á lingua portugueza was also published in 1887, José Prévôt (1887, p. [I]) being mentioned as the sole author. Within the framework of my bibliographic evaluation, I was able to trace a total of ten editions $\left({ }^{1} 1887,{ }^{2} 1901,{ }^{3} 1905,{ }^{4} 1912,{ }^{5} 1929,61957,{ }^{7} 1961,{ }^{8} 1963,{ }^{9} 1968,{ }^{10} 1974\right)$, the last five of which were not printed in Heidelberg but in São Paulo, Brazil (cf. KEMMLER, 2021a, p. 155-159). Since the text of the German elementary grammar also underwent several revisions from the third edition onward, only the first edition will be considered for this study.

\section{Comparison of the conversation grammars}

From a structural point of view, the contents of Otto's French conversation grammar of the German language can be presented as follows (cf. OTTO, 1882):

$1311^{\text {th }}$ edition, 1916 (OCLC 634546621, 718969612, 72710123); $12^{\text {th }}$ edition, 1919 (OCLC 635980893, 719102952, 900673277, RK); $13^{\text {th }}$ edition, 1924 (OCLC 804520978, 901700383, 1033701422); 14 ${ }^{\text {th }}$ edition, 1934 (OCLC 401295734, 497092938, 1040351103); 15 $5^{\text {th }}$ edition, 1952 (OCLC 73609033, 632236231, 984932300); 16 $6^{\text {th }}$ edition, 1956 (OCLC 7016222, 1009920413); $17^{\text {th }}$ edition, 1961 (OCLC 73609038, 756371458 ); $18^{\text {th }}$ edition, 1965 (OCLC $\left.756372699,74518325,1069926113\right)$. From the $12^{\text {th }}$ edition on, the elementary grammar consistently occupies XII, 230 pages, according to WorldCat. 


\title{
REVISTA DA ABRALIN
}

\author{
[I] [Title page] \\ [III]-X Préface de la sixième [douzième] édition \\ [X]-XIII Table des matières \\ XIV-XVI Table alphabétique des matières \\ [XVIII-XIX] [Facsimile pages in Gothic letters:] Écriture allemande \\ 1-252 Première Partie: Lexicologie \\ 1-13 Introduction \\ 14-248 Première Leçon - Quarante-unième Leçon \\ 249-252 Exercices généraux \\ 253-361 Seconde Partie: Syntaxe \\ 255-343 Quarante-deuxième Leçon - Cinquante-quatrième Leçon \\ 344-361 Exercices généraux: Suite de la page 252 \\ 362-386 Appendice: Morceaux choisis de poésie allemande \\ 387-401 Vocabulaire: I Partie allemande \\ 402-422 Partie française
}

In addition to the introductory paratextual elements, it is particularly noticeable that Otto (1882) divides the conversation grammar into two parts. The first part, called Lexicologie [lexicology], plays a central role, comprising about 60 percent of the total pages in the volume. This seems to be obvious, since behind this term is hidden what Otto (1865, p. [X], [XV], 13) still calls Etymologie [etymology] in the second edition of his textbook, which ultimately corresponds to the modern concept of morphology. However, this part is preceded by the Introduction, which is largely not part of morphology, but devotes 11 pages to a morphophonetic and prosodic introduction while offering a one-page introduction to the parts of speech only at the end (OTTO, 1882, p. 13). In the 12th edition, Otto (1882) has a total of 181 numbered German-French or French-German translation exercises called Exercice or Thème [exercise, theme], which are always found at the end of the respective lesson or grammar unit. In addition, at the end of the two parts there is a total of 25 Exercices généraux [general exercises] in the language direction French-German (OTTO; PRÉVÔT, 1887, p. 249-252, 344-361).

With about 58 percent, Otto and Prévôt's text (1887) shows a largely similar percentage of the morphology part called Lexicologia. ${ }^{14}$ Moreover, like the French edition, this part comprises 41 lessons, which are arranged in accordance with the content (which also applies to the corresponding German reading texts):

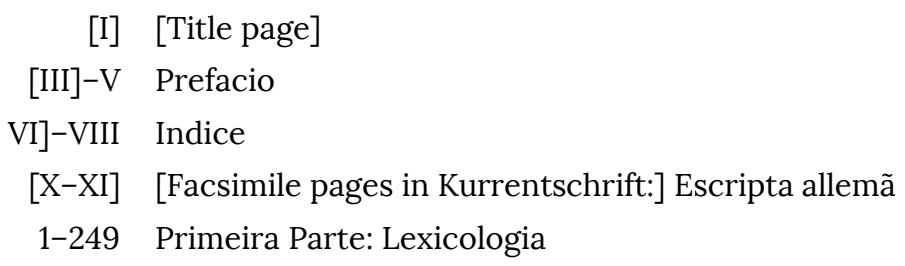

14 Alternatively, Otto; Prévôt (1887, p. 79) explicitly use the term 'morphologia'. 


\section{REVISTA DA ABRALIN}

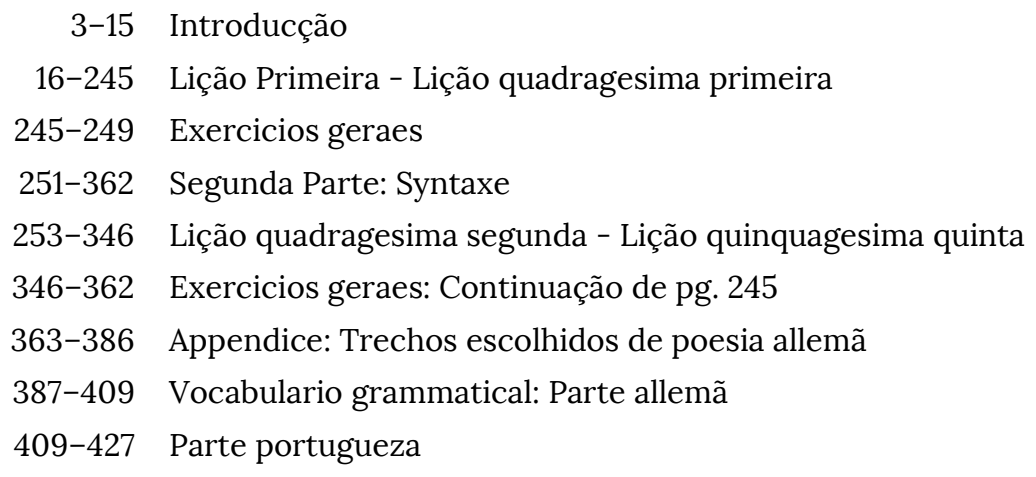

Despite all basic agreement in formal respects, José Prévôt (in OTTO; PRÉVÔT, 1887) does without the separate table of contents, "Table alphabétique des matières", which was to last until the end of the nineteenth century at least in the French editions of the German conversation grammar. In the Portuguese tradition, Prévôt incorporated the contents of this metalinguistic index into the German-Portuguese and Portuguese-German vocabulary lists in the form of a «Vocabulario grammatical» ever since the very first edition. Similar to its model, Otto; Prévôt (1887) lists a total of 182 numbered German-Portuguese or Portuguese-German translation exercises designated as Exercicio or Thema, to which are added another 25 «Exercicios geraes» in the Portuguese-German language direction (OTTO; PRÉVÔT, 1887, p. 245-249, 346-362).

While the actual text of the French conversation grammar ends with the «Cinquante-quatrième Leçon: De la phrase composée», Otto; Prévôt (1887, p. 343-346) the «Lição quinquagesima quarta: Da phrase composta» is followed by an additional 55th lesson with the title «Lição quinquagesima quinta: A. Da ponctuação. B. Das majusculas». In just under two and a half pages, the author of the German textbook in Portuguese wishes to make his target audience aware of the differences between the rules of punctuation and capitalization of their native language and of German as an object language.

As mentioned in 1.3, the first two editions of Prévôt's German textbook appeared with the indication «Adaptada ao uso dos portuguezes por José Prévôt» (see also KEMMLER, 2021a, p. 122-123). Moreover, it is clear from the preface to the first edition that Prévôt did not see his role as a 'simple' translational achievement, but that his ultimate intention in adapting the French textbook penned by Emil Otto to serve a purely Portuguese-speaking target audience was that Portuguese learners of German would not have to continue to rely on using the French language edition (PRÉVÔT, 1887, p. IV). To gain insight into Prévôt's treatment of Otto's text, let us compare below a selection of textual examples from the French edition in Mauron's adaptation with the first Portuguese editions. ${ }^{15}$

15 For quotations, the text configuration of the late nineteenth century editions is largely respected. Thus, the historical orthography is retained, as well as italics and bold type as typographical features. The Fraktur font for German words is replaced by the modern character set Arial. 


\section{REVISTA DA ABRALIN}

déclinaisons et sur la raison de leur division. Les uns en adoptent six. d'autres cinq, d'autres quatre, et même trois, ou deux seulement. Cette division est tout à fait arbitraire. Cela provient de ce que la langue allemande a été parlée et formée par différentes tribus d'une manière différente, avant que des règles fixes fussent établies à 1'égard de la déclinaison, de sorte que plus tard les grammairiens furent obligés d'accepter ces différentes formes comme des faits accomplis, et d'en tirer le meilleur parti possible (OTTO, 1882, p. 19). razão da sua divisão. Uns adoptam seis, outros cinco, outros quatro, outros até tres ou duas. Esta divisão é arbitraria. As differentes declinações, formadas entre as tribus separadas em antes de fixadas as regras uniformes sobre a declinação, entraram na lingua e foram desde então systematisadas por differentes modos (OTTO; PRÉVÔT, 1887, p. 21).

In his introduction to the nominal declension of German in the third lesson, Otto (1882) briefly discusses the number of inflectional classes used by German grammarians, which can range from two to seven (see also KEMMLER, 2021b, p. 75-81). Arguably correctly, Emil Otto emphasizes the fundamental arbitrariness of such a distinction in the French edition. José Prévôt follows this assessment unreservedly in his faithful translation. However, in his historical explanation of the origin of declension, he refrains from a literal correspondence: while Otto (1882) attributes its genesis to differences in the languages of different tribes, which ultimately would have forced a different codification by grammarians, Prévôt here seems to prefer a somewhat vague fixation of changes in language use that are less determined by their origin.

Nevertheless, Otto considers in his textbook a five-member inflectional class system based on the genus and on the number of syllables:

Cependant on y reconnaît aisément deux idées fondamentales, qui tiennent au génie même de la langue, et sur lesquelles reposent les differentes déclinaisons: ce sont le genre, puis le nombre des syllabes. Quoique ce système présente aussi quelques irrégularités, il offre pourtant bien moins de difficultés que toute autre division. II est évident que chaque genre a son inflexion particulière, selon le nombre de syllabes, et que les substantifs masculins se divisent entre eux, selon leur terminaison, en trois classes. Ce système présentera cinq déclinaisons: trois pour les
É facil, porém, reconhecer que as ideias fundamentaes das declinações são: a) o genero, b) o numero das syllabas. Os generos sendo tres, teriamos já tres declinações: mas subdividindo os substantivos masculinos em tres classes, conforme a suas terminações, teremos cinco.

Cada genero tem flexões particulares correspondentes ao numero das syllabas (OTTO; PRÉVÔT, 1887, p. 22). 


\title{
REVISTA DA ABRALIN
}

substantifs masculins, une pour les féminins, et une pour les neutres (OTTO, 1882, p. 19).

In this case, Prévôt's translation is somewhat freer, foregoing the linguistic ideological concept of the génie de la langue as a special character of the language, as well as considerations of irregularity within the inflectional class system he proposes. On the other hand, Prévôt's presentation seems much shorter and more technical, as the translator limits himself to the essential information on the inflectional class system.

The tenth lesson is devoted to the declension of compound nouns. Since the French language does not know analytic word-formation such as the German composition, the grammarian first gives three examples and mentions three of the German fugue elements:

\begin{abstract}
On appelle substantif composé celui dans la
Compostos chamam-se os substantivos em formation duquel entrent deux ou plusieurs mots. Ex.: Hausvater, de Haus maison et Vater père; Neujahr le nouvel an, de l'adjectif neu nouveau, et de Jahr l'an; Baukunst l'architecture, du verbe bauen bâtir, et de Kunst l'art (l'art de bâtir). Il faut aussi remarquer que quelquefois il y entre une lettre euphonique (e, $\mathbf{n}$ ou $\mathbf{s})$. cuja formação entram duas ou mais palavras. Ex.: Hausvater, de Haus casa e Vater pae; Neujahr o ano bom, de neu novo e Jahr anno; die Baukunst a architectura, do verbo bauen construir e Kunst a arte (a arte de construir). Ás vezes tambem entre uma lettra eufónica $(\mathbf{e}, \mathbf{n}, \mathbf{s})$. Isto só póde ter logar quando a primeira parte é complemento restrictivo da segunda; p. ex.: das La déclinaison des substantifs Volkslied, canto popular, canto do povo; dépendant de leur genre, il faut savoir que le mas nem sempre se põe esta lettra, Em gegenre des substantifs composés est toujours celui du dernier des deux mots. Par ex.: die Hausthüre est fém., quoiqu'on dise das Haus; ral póde-se dizer que o ultimo termo é o principal, cuja ideia simples persiste na car le second mot die Thüre donne son composição, sendo o anterior complegenre à la composition „Hausthüre“. Il s'ensuit que ce mot se décline d'après la quatrième déclinaison. Il faut remarquer en outre que la première partie reste tout à fait invariable (OTTO, 1882, p. 45).
\end{abstract}

Prévôt incorporates Otto's first paragraph along with examples, without any changes. On the other hand, Prévôt partially reworks the second paragraph, emphasizing the relationship between the 'primary word' in last place and the 'determinative element' in first place, but without taking up Otto's example of the Haustür. Prévôt adopts the last sentence of this paragraph, which refers to the invariability of the determinative element, almost verbatim. 


\section{REVISTA DA ABRALIN}

The following statement, on the other hand, is completely new and reflects Prévôt's personal assessment of the outstanding importance of composition as a process of word formation of the German language in comparison to its subordinate importance to the Romance languages:

O numero d'estas combinações é illimitado e constitue para a lingua allemã uma riqueza de que carecem, em muitos casos, as linguas de derivação latina (OTTO; PRÉVÔT, 1887, p. 48).

Taking into account the importance of the so-called article partitif [partitive article] in French to denote indefinite quantities, Otto (1882, p. 48-50) devotes the entire 11th lesson, titled «Le sens partitif», to this grammatical phenomenon:

1) Ce qu'on appelle en français l'article partitif, il ne faudrait l'appeler dans la langue allemande que le sens partitif ou le sens non déterminé, parce qu'en allemand on exprime cette idée précisément par l'absence de tout article. Ainsi $d u$ vin se rend par le simple mot Wein; de la viande Fleisch; de l'or Gold. De même au pluriel des livres books; des enfants children etc. et ainsi de suite.

2) Cette forme est aussi employée en allemand après un nom qui exprime une mesure, un poids, un nombre etc., ainsi qu'après tous les termes de quantité (viel, wenig, mehr \&c.) c'est-à-dire de est supprimé (OTTO, 1882, p. 48-49).
Tendo o artigo partitivo desapparecido do portuguez moderno até alguns vestigios, inutil será mencional-o.

O substantivo que indica medida, peso, numero, etc., nunca se liga ao determinado por meio de preposição, como acontece em portuguez. Eine Flasche Wein, uma garrafa de vinho. Ein Glas Wasser, um copo de água. Ein Stück Käse, um pedaço de queijo. Alguns substantivos que indicam pezo, etc. exacto, ficam no singular. Ex.: zwei Paar Schuhe, drei Pfund Kirschen, zwei Dutzend Eier (OTTO; PRÉVÔT, 1887, p. 51).

Since in most cases the French partitive article corresponds in German to the omission of the definite article, it seems quite plausible that Otto emphasizes this phenomenon for his French target audience. On the other hand, the account in the Portuguese edition seems to be somewhat different: Prévôt points out under the heading «O sentido partitivo» that there is no longer a partitive article strictu sensu in Portuguese. Since this phenomenon is equally absent in German, the examples given here correspond more to the successor of the historical genitivus partitivus, which in modern German grammar is called 'Apposition mit Maßangabe' [apposition with indication of measure] (Eisenberg, 2013, II, p. 260-262). In this case, Prévôt clearly could not follow his French model, with the result that this lesson is not really convincing.

Following the paradigm of the auxiliary verb haben, the following note on the syntax of sentences with analytic verb forms in which the auxiliary verb and the full verb are separated in the form of an infinitive or participle is found in the 16th lesson in both textbooks in the section «Remarques sur la construction allemande» / «Observações sobre a construcção allemã»: 


\section{REVISTA DA ABRALIN}

Comme le chapitre sur la Construction ne viendra qu'après l'exposition de toutes les parties du dis- cours, il faut en attendant observer ce qui suit:

1) Dans une proposition contenant un temps composé, le participe ou l'infinitif se placent à la fin. Dans l'ordre ordinaire le sujet occupe la première place; le verbe auxiliaire, la deuxième; le régime, la troisième; l'expression adverbiale, la quatrième; et le participe passé ou l'infinitif termine la proposition (OTTO, 1882, p. 73).
Depois da Lexicologia (Morphologia) fallaremos detidamente na construcção; mas convem expôr desde já as regras seguintes:

1. nas orações cujo verbo está n'um tempo composto, tanto o participio como o infinito vão ao fim da oração. Em allemão ha frequentes inversões, mas a ordem ordinaria das differentes partes da oração é a seguinte: sujeito, verbo auxiliar, complemento directo ou ind., compl. circumst. quando subst., participio passivo ou infinito (OTTO; PRÉVÔT, 1887, p. 79).

The text of the two paragraphs largely agrees. However, there is a more consistent use of metalinguistic terms in the Portuguese translation. In addition to conventional terms such as 'sujeito' and 'verbo auxiliar' for subject and auxiliary verb, Prévôt also employs 'complemento directo' [accusative object], 'complemento indirecto' [dative object], and 'complemento circumstancial' [adverbial clause], which in orthographic adaptation correspond to the terms 'complemento direto', 'complemento indireto', and 'complemento circunstancial', still common in Portuguese today. In addition, there is the German Partizip Perfekt [perfect participle] (today also known as Partizip II), called 'participe passé' by Otto (1882), for which Prévôt, in obvious reference to the Latin tradition, chooses the term 'participio passivo'.

There is also widespread agreement in the presentation of modal verbs in the 19th lesson in both textbooks in the section «Remarques sur la construction allemande» / «Observações sobre a construcção allemã»:

\footnotetext{
Aux trois auxiliaires précédents il faut Estes verbos enunciam uma possibilidade, ajouter les six suivants, qui servent à uma vontade, um dever, uma necessidade modifier les verbes en exprimant une ou uma licença de se praticar uma acção. possibilité, une volonté, un devoir, une São os seguintes: können, wollen, sollen, nécessité ou une permission de faire l'action. müssen, mögen, dürfen. São irregulares no Ce sont: können, wollen, sollen, müssen, presente do indicativo (OTTO; PRÉVÔT, mögen, dürfen. Ils ne sont irréguliers qu'au 1887, p. 88). singulier du présent (OTTO, 1882, p. 82).
}

While Otto emphasizes the modal character of the modal verbs next to the already presented auxiliary verbs as an introduction, Prévôt is content with emphasizing their meaning and naming them in the same order. In doing so, however, the last sentence, «Ils ne sont irréguliers qu'au singulier du présent», does not seem to be translated quite correctly, since the French ne que as 'only' 


\section{REVISTA DA ABRALIN}

remains untranslated, but the translation «Só são irregulares no singular do presente [do indicativo]» seems more appropriate.

Unsurprisingly, the question of gender equivalence is addressed more often. This is the case, for example, in the 25th lesson, in which the personal pronouns are introduced. Otto (1882) discusses the French correspondence of the three German genera quite extensively as follows:

\footnotetext{
$\S 5$. Comme en allemand il y a trois genres, $§ 5$. convem reparar no genero do substantandis qu'en français il n'y en a que deux; tivo que o pronome substitue, para pôr o comme de plus le genre des substantifs ne genero apropriado do pronome (OTTO; répond pas toujours au genre des mots PRÉVÔT, 1887, p. 129). français, les pronoms de la troisième personne "il" et "elle" doivent être traduits tantôt par er, tantôt par es et tantôt par sie, et ainsi de suite dans les autres cas. Cela dépend uniquement du genre du substantif que le pronom il ou elle remplace; c'est à quoi il faut toujours faire attention (OTTO, 1882, p. 124).
}

In contrast to his French model, Prévôt refrains from similar explanations and keeps it correspondingly short by simply reproducing the last half-sentence, according to which one must be attentive when using the genus.

\section{Comparison of the elementary grammars}

The second (OTTO, 1871) and fifth editions (see OTTO, 1881) of the French elementary grammar of the German language have the same page count of xii, 172 pages, the contents of which can be broken down as follows:

[I] [Title page]

[III]-VI Préface de la première [cinquième] édition

VII]-VIII Table des matières

[X-XI $\quad$ [Facsimile pages in Gothic letters:] Écriture allemande

1-8 De la prononciation

8-9 Des parties du discours

9-142 Première Leçon - Cinquante-cinquième Leçon

143-154 Exercices et thèmes généraux

155-172 Appendice: 


\section{REVISTA DA ABRALIN}

1. recueil de mots

2. expressions faciles

3. anecdotes, fables et historiettes allemandes

Following the preface to the first edition and the preface to the fifth posthumous edition, for which the publisher is responsible, Otto (1881) abandons the division of the elementary grammar into two parts that is analogous to the conversation grammar. This is because this work deals exclusively with aspects of morphology, as the author notes:

\footnotetext{
Le petit livre, qui ne contient que la lexicologie, est divise en 55 'Leçons' rattachées entre elles par un lien systématique et formant un ensemble complet. Un certain nombre de points d'arrêt offrent à 1'élève 1'avantage de voir à chaque moment et d'un coup d'œil le chemin parcouru de se rappeler aisément ce qu'il à pu oublier [...] (OTTO, 1881, p. IV).
}

Even if syntax is deliberately not given its own section, word order is always implicitly taken into account, and Emil Otto ultimately relies here on the progression underlying his work, with exercises primarily based on bilingual translation exercises. The 55 lessons, which themselves have a total of 122 translation exercises, are followed by another 34 «Exercices et thèmes généraux» as translation exercises, alternating between the two language directions.

In contrast to the conversation grammar, which is attributed to Emil Otto as the author, José Prévôt identifies himself as the sole author of the Portuguese edition of the German elementary grammar, both on the title page and in the preface. Even at first glance, he seems to distance himself from Otto's elementary grammar, since his Portuguese edition now contains 70 lessons instead of the 55 lessons in the French work:

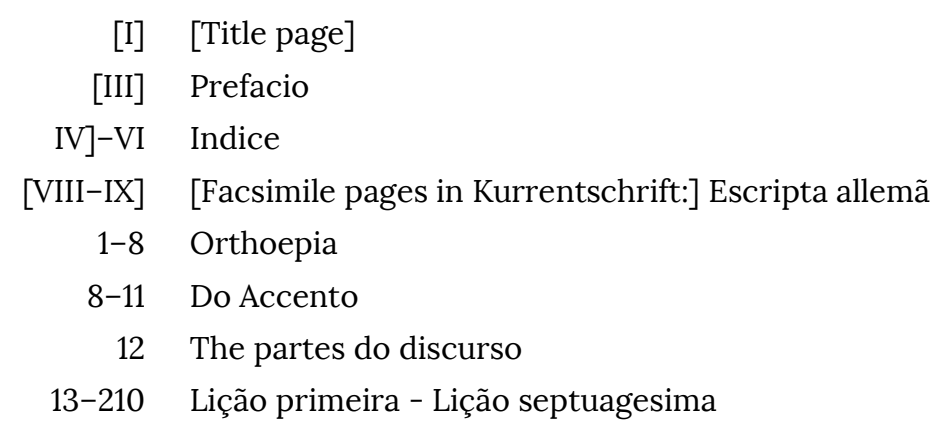

At a glance, it becomes apparent that Prévôt (1887) dispenses with other paratextual elements besides the preface and the table of contents, which means that the work is limited to the introductory presentation of the graphophonetic inventory and the parts of speech, then proceeding immediately to the 70 lessons, all of which are devoted to morphology. As usual, the German-Portuguese and Portuguese-German translation exercises, numbered 1-142, follow at the end of each lesson. 


\section{REVISTA DA ABRALIN}

To introduce the German nominal declension, the French edition of the elementary grammar contains a significantly revised and reduced text in relation to what is found in the conversation grammar, while the Portuguese explanation here is much more comprehensive.

Il y a cinq déclinaisons, trois pour les substantifs masculins, une pour les féminins et une pour les neutres (OTTO, 1881, p. 14).
Os grammaticos allemães divergem com relação ao numero das declinações e á razão da sua divisão. Uns adoptam seis, outros cinco, outros quatro, outros até tres ou duas. Esta divisão é arbitraria.

É fácil, porém, reconhecer que as ideias fundamentaes das declinações São: a) o genero, b) o numero das syllabas. Os generos sendo tres, teriamos já tres declinações; mas subdividindo os substantivos masculinos em tres classes, conforme as suas terminações, teremos cinco.

Cada genero tem flexões particulares correspondentes ao numero das syllabas (PRÉVÔT, 1887, p. 19).

Prévôt (1887, p. 19), on the other hand, largely adopts the explanation of declension offered by the conversation grammar (OTTO; PRÉVÔT, 1887, p. 21) and also applies Otto's five-member inflectional class system, but omits the historical explanation given in Otto; Prévôt (1887, p. 21) for the grammaticalization of declension.

While Otto (1881) does not describe composition as a word-forming strategy at all, in contrast to the French conversation grammar, in Prévôt's elementary grammar, the 13th lesson is devoted to the declension of compound nouns (PRÉVÔT, 1887, p. 47-49). Thus, the lesson titled «Declinação dos substantivos compostos» in Prévôt (1887, p. 47) begins with exactly the same explanatory text as the conversation grammar text reproduced above in chapter 3 (see OTTO; PRÉVÔT, 1887, p. 47-48). Since there are also explanations and examples of the first and second declensions to be found (but not of the other three, which are described in OTTO; PRÉVÔT, 1887, p. 48-49), it seems obvious that Prévôt used here the text of his conversation grammar, to which he added completely new exercises for translation and conversation, which will not be discussed in detail here.

Similar to what could be observed regarding the corresponding conversation grammar, the French partitive article or its German equivalent is considered quite extensively in Otto (1881, p. 2729). However, the explanation with which Emil Otto begins the lesson does not draw on the text of the conversation grammar, but is new: 


\section{REVISTA DA ABRALIN}

L'idée que représente en français l'article partitif (du vin, des livres etc.) s'exprime en allemand par le substantif seul sans aucun article. Ainsi du vin se rend par le simple mot Wein; de même au pluriel des livres Bücher (OTTO, 1881, p. 27).

Since this phenomenon, as discussed above, has no comparable meaning in Portuguese, the corresponding 15th lesson in Prévôt (1887, p. 52-53) is limited to unchanged reproduction of the explanatory text reproduced above together with the associated notes (cf. OTTO; PRÉVÔT, 1887, p. 51), as well as translation and conversation exercises on what can be translated as 'apposition with indication of measures'.

As for the syntactic explanations of word order in sentences with analytic verb forms, Otto (1881, p. 48) adopts the text from the conversation grammar without any changes, in much the same way that Prévôt (1887, p. 85) here is identical in text to Otto; Prévôt (1887, p. 79), though Prévôt (1887, p. 85-86) offers nine notes instead of the seven notes of the conversation grammar.

In contrast to the corresponding conversation grammar, the French elementary grammar completely omits an explanation of the nature of modal verbs in the 22nd and 23rd lessons and confines itself to presenting an excerpt of their conjugation on the basis of the present indicative and preterite (see OTTO, 1881, p. 55-58). Prévôt (1887, p. 95), on the other hand, reproduces without changes the brief explanation of the «Observações sobre a construcção allemã» found in Otto; Prévôt (1887, p. 88), and subsequently gives an overview of the paradigms of the six modal verbs in the indicative and subjunctive in the 29th and 30th lessons (PRÉVÔT, 1887, p. 95-97, 99-100).

Finally, the paragraph concerning the use of German genders is now to be found in the 33rd lesson of Otto (1881).

\footnotetext{
3) Comme en allemand il y a trois genres, tandis qu'en français il n'y en a que deux, il s'ensuit que les pronoms de la troisième personne »il« et »elle« doivent être traduits tantôt par er, tantôt par es et tantôt par sie, et ainsi de suite dans les autres cas. Cela dépend du genre du substantif que les pronoms il, elle, le, la remplacent (OTTO, 1881, p. 81).
}

\begin{abstract}
$\S 4$. Convem reparar no genero do substantivo que o pronome substitue, para pôr o genero apropriado do pronome (PRÉVÔT, 1887, p. 137).
\end{abstract}

The French observation is formally only slightly changed, but the last half-sentence, which contained the reference to the special care (grande attention; cf. OTTO, 1882, p. 124) in the genders was deleted. The short remark calling for care in the use of German genders, found in Otto; Prévôt (1887, p. 129), is now in the 42nd lesson, which continues the remarks on personal pronouns from the 41st lesson. Here, only the paragraph number has changed (§ 4 instead of $\S 5$ ). 


\section{REVISTA DA ABRALIN}

\section{Conclusions}

In this article, I have made the first attempt to contrast the French and Portuguese traditions of Emil Otto's and José Prévôt's German textbooks, respectively, both having been published in the late nineteenth century by the Julius Groos Verlag in Heidelberg.

As the very first German textbook of what would become known as the Method Gaspey-OttoSauer (MGOS), the conversation grammar Nouvelle grammaire allemande first appeared in 1857 and had at least 23 editions in various adaptations until 1942. The corresponding elementary grammar, titled Petite grammaire allemande, was somewhat less successful than the more comprehensive work, with 18 recorded editions until 1965.

The conversation grammar for a Portuguese target audience was first published in Portuguese in 1887 under the title Nova grammatica allemã theorica e pratica. In the first two editions, the work was still published under the name of Emil Otto, José Prévôt initially assuming responsibility only as an editor. In total, seven editions of this work appeared in eight imprints until 1942, and underwent several adaptations. The elementary grammar published in the same series appeared in the same year under the title Grammatica elementar allemã, whereby José Prévôt ascribes himself the authorship from its first edition. Up to 1974, the elementary grammar appeared in a total of ten editions in several adaptations.

The text of the Portuguese first edition is based on the 12th edition published by Alexandre Mauron (1829-1891) in 1882. In the configuration of this edition, the French language Nouvelle grammaire allemande (1857) has a total of XX pages of preliminaries as well as 422 pages of text in 54 lessons, 25 separate translation exercises, a collection of literary texts, and a German-French or French-German vocabulary. That the Portuguese first edition of the Nova grammatica allemã theorica e pratica ('1887), with XII pages of preliminaries and 427 pages of text, used just this posthumous French edition as a basis for the text compilation becomes obvious here, if only in terms of its size. Prévôt follows the arrangement of the lessons in this edition of Otto's textbook and deviates only at the end of his Portuguese edition by adding to it a new 55th lesson in which the most important differences between punctuation and capitalization in Portuguese and German are briefly presented. In addition, Prévôt does not separately print the table of contents with metalinguistic terms that Otto places at the beginning of his textbook, but integrates these contents into the vocabulary section under the heading «Vocabulario grammatical».

A comparative examination of seven text excerpts of the metalinguistic description in Otto (1882) and Otto; Prévôt (1887) reveals that José Prévôt's adaptation can only be regarded as a pure translation to a very limited extent. While literal translations can occasionally be demonstrated, Prévôt mostly strives for a translation of the French text that is faithful to the meaning. In doing so, however, he often refrains from reproducing textual components that he obviously considers too verbose or possibly even superfluous, or that are decidedly addressed to Otto's French target audience, which ultimately leads to a freer translation of the source text. When possible, Prévôt attempts to supplement his metalinguistic explanation with linguistic comparative notes. Since he himself was not a native speaker of Portuguese, this does not always succeed, as can be seen in the case of the French partitive article. Otherwise, it can be stated that Prévôt, in comparison to the French original, resorts to modern metalinguistic terms that are still familiar today. 


\section{REVISTA DA ABRALIN}

Finally, with regard to the large number of translation exercises and vocabulary lists found in both works, Prévôt does adopt much from the original French text, although a larger number of changes can also be discerned. Since this subject is beyond the scope of the present study, I think it appropriate to undertake an investigation of the fate of these practical elements of Prévôt's textbook on another occasion.

As for the French language elementary grammar Petite grammaire allemande (1870) and its Portuguese language counterpart Grammatica elementar allemã (1887), my investigation has revealed that the two works, while concurring in their focus on morphology, represent distinctly different expressions within the same text genre of the MGOS. From the first edition until 1896, the French language tradition maintains a page count of XII, 172 pages, while the first Portuguese language edition not only has a count of X, 210 pages, but, with 70 lessons and the absence of further exercises and appendices, has an entirely different structure.

In fact, it can be concluded that Otto (1881) tends for the most part to present a new, shorter, metalinguistic explanation in the passages I have examined, while Prévôt (1887) tends towards taking over-mostly without changes-some of the textual components originating from the conversation grammar he himself translated. In this sense, changes, if they occur, are mostly connected with reductions in the textual volume of the metalinguistic explanations. Thus it can be stated that for the Grammatica elementar allemã (Prévôt, 1887), from the point of view of content, the Petite grammaire allemande (Otto, 1881) cannot be considered as a direct model, as would have been expected, but rather the Nova grammatica allemã theorica e pratica, which is also indebted to José Prévôt. It remains unquestioned that Prévôt may have let himself be guided by the basic order of the lessons in Otto's French elementary grammar, although he himself increased the number of lessons by almost 30 percent.

\section{REFERENCES}

BOURQUI, A[lexis]. Nécrologie: $\mathrm{m}$. le $\mathrm{d}^{\mathrm{r}}$. Alexandre Mauron. Nouvelles étrennes fribourgeoises: Almanach des villes et des campagnes, v. 26, p. 68-71, 1892.

CHOPPIN, Alain ; RODRÍGUEZ, Fabiola; PINHEDE,Bernard. Les manuels scolaires en France de 1789 à nos jours: tome 5: les manuels d'allemand. Paris: Institut National de Recherche Pedagogique; Publications de la Sorbonne (Emmanuelle: Service d'histoire de l'éducation; 5), 1993.

EISENBERG, Peter. Grundriss der deutschen Grammatik Band 2: Der Satz. Unter Mitarbeit von Rolf Thieroff, 4 , aktualisierte und überarbeitete Auflage, Stuttgart; Weimar: Verlag J. B. Metzler, 2013, II.

KEMMLER, Rolf. Die frühesten portugiesischen Deutschlehrwerke (1863-1926). Zweite, überarbeitete Auflage. Vila Real: Centro de Estudos em Letras; Universidade de Trás-os-Montes e Alto Douro (Coleção Linguística; 12), ${ }^{2} 2021^{\mathrm{a}}$. hdl.handle.net1034810689. Last access: 23 September 2021.

KEMMLER, Rolf. Die 'Grammatik-Übersetzungsmethode' in den ältesten portugiesischen Deutschlehrwerken. Zweite, überarbeitete Auflage. Vila Real: Centro de Estudos em Letras; Universidade de Trás-os-Montes e Alto Douro (Coleção Linguística; 13), ${ }^{2}$ 2021b. hdl.handle.net10348106901. Last access: 23 September 2021. 


\section{REVISTA DA ABRALIN}

OTTO, Emil. Französische Conversations-Grammatik zum Schul- und Privatunterricht. Nach einer neuen, practischen Methode bearbeitet von Emil Otto, Zweite verbesserte und vermehrte Auflage, Heidelberg: Julius Groos, Verlag, 1854.

OTTO, Emil. Nouvelle grammaire allemande: contenant outre les principales règles de la langue allemande, des thèmes, des lectures et des conversations, d'après une méthode à la fois théorique et pratique. Second edition, Heidelberg; Paris; Brussels: Julius Groos, Éditeur; A. Franck; Kissling \& Cie., 1865.

OTTO, Emil. German conversation-grammar: a new and practical method of learning the German language. Tenth edition. Leipzig; Heidelberg; London; Paris; New York: Julius Groos, 1870.

OTTO, Emil. Petite grammaire allemande: abrégée, accompagnée de nombreux exercices de conversation et de lecture, a l'usage des commençants, d'après une méthode a la fois théorique et pratique. Second edition. Heidelberg; Paris; Brussels; Genève: Julius Groos, Éditeur; A. Franck, Haar \& Steinert; Kiessling \& Co.; Charles Muquardt; H. Georg; Müller-Darier, 1871.

OTTO, Emil. Petite grammaire allemande: abrégée, accompagnée de nombreux exercices de conversation et de lecture, a l'usage des commençants, d'après une méthode a la fois théorique et pratique. Fifth edition. Heidelberg; Paris; Nancy; Genève, Metz; Strasbourg; Brussels; Anvers; London; Florence; Milan; Naples; Turin; Rome; Venice; Verona; Madrid; Buenos-Aires: Julius Groos, Éditeur; Fr. Vieweg; Veuve Boyveau; A. Ghio; Haar \& Steinert; G. Fischbacher; MesnilDramard; J. Baer; Ract \& Falquet; Sidot Frères; R. Burckhardt - H. Georg; Desrogis (J. Sandoz, successeurs); Even, Frères; Librairie Allemande (Lang \& Rasch), G. Scriba, jeune; K. J. Trübner, Treuttel \& Würtz; J. Bensheimer - R. Schultz \& Cie.; Agence de B. Herder; J. Noiriel - C. F. Schmidt; Kiesling \& Cie.; Lebègue \& Cie.; Ch. Muquardt; M. Kornicker; David Nutt; Dulau \& Co.; S. Low \& Co.; Trübner \& Co.; H. Loescher; U. Hoepli; U. Hoepli (F. Furchheim); H. Loescher; Loescher \& Comp.; Ferdinando Ongania, Successore; H. F. \& M. Münster; H. F. \& M. Münster, Librairie; C. Bailly-Baillière, Librería Nacional y Extranjera; Librería Nacional y Extranjera (Fernando Holm); Ernst Nolte, 1881.

OTTO, Emil. Nouvelle grammaire allemande: contenant outre le principales règles de la langue allemande, des thèmes, des lectures et des conversations d'après une méthode a la fois théorique et pratique. Twelfth edition. Revue et corrigée par A. Mauron, Dr. et Professeur, Heidelberg; Paris; Nancy; Genève, Metz; Strasbourg; Anvers; Brussels; Londres; Florence; Milan; Naples; Turin; Rome; Venise; Madrid: Jules Groos, Éditeur; Fr. Vieweg; Veuve Boyveau; A. Ghio; Haar \& Steinert; G. Fischbacher; Librairie Européenne de Baudry; Ract \& Falquet; Sidot Frères; H. Georg; Desrogis (J. Sandoz, successeurs); Th. Müller (C. Menz, successeur); Even, Frères; Librairie Allemande (Lang \& Rasch), G. Scriba; J. Bensheimer - R. Schultz \& Cie.; Agence de B. Herder; J. Noiriel - C. F. Schmidt; K. J. Trübner, Treuttel \& Würtz; M. Kornicker; Kiesling \& Cie.; Ch. Muquardt; H. Manceaux; David Nutt; Dulau \& Co.; S. Low \& Co.; Trübner \& Co.; H. Loescher; U. Hoepli; Detken \& Rocholl; H. Loescher; Loescher \& Comp.; Ferdinando Ongania, Successore; H. F. \& M. Münster; C. Bailly-Baillière, Librería Nacional y Extranjera; Librería Nacional y Extranjera (Fernando Holm), 1882.

OTTO, Emil. An elementary grammar of the German language: combined with exercises, readings and conversations. New York, Boston: Henry Holt and Company, Carl Schoenhof, 1890.

OTTO, Emil. Corrigé des versions et thèmes contenus dans la grammaire allemande. Sixth edition. Paris, Heidelberg, London, Rome, St. Petersburg: Julius Groos, 1902.

OTTO, Emil; PRÉVÔT, José. Nova grammatica allemã theorica e pratica: contendo alem das principaes regras da lingua allemã , themas e exercicios de leitura e de conversação. Adaptada ao uso dos portuguezes por José Prévôt, Professor Particular no Porto, Lisboa; Braga; Porto; Rio de Janeiro; Madrid; Buenos Aires; Valparaiso; Heidelberg: Tavares Cardozo e Irmão; Antonio Telles de Menezes; Livraria Popular; Magalhães e Moniz, Livraria Universal; Lämmert \& Cie.; Richard Matthes; Fuentes y Capdeville; Libreria Nacional y Extranjera (Fernando Hohn); L. Jacobsen \& Cie., Libreria Europea; C. Kirsinger \& Cie.; C. F. Niemeyer (Libreria Universal); Julio Groos, editor (Methodo Gaspey-OttoSauer), 1887. 


\section{REVISTA DA ABRALIN}

PRÉVÔT, José. Grammatica elementar allemã. Adaptada á lingua portugueza por José Prévôt, professor particular no Porto, Lisboa; Braga; Porto; Rio de Janeiro; Madrid; Buenos Aires; Valparaiso; Heidelberg: Tavares Cardozo e Irmão; Antonio Telles de Menezes; Livraria Popular; Magalhães e Moniz, Livraria Universal; Lämmert \& Cie.; Richard

Matthes; Fuentes y Capdeville; Libreria Nacional y Extranjera (Fernando Hohn); L. Jacobsen \& Cie., Libreria Europea; C. Kirsinger \& Cie.; C. F. Niemayer (Libreria Universal); Julius Groos, 1887.

WORLDCAT. http://www.worldcat.org. Last access: 23 September 2021. 